\title{
Om åndssvake i etterkrigstidens Norge
}

\begin{abstract}
SAMMENDRAG Artikkelen omhandler Gaute Heivolls siste roman Over det kinesiske hav, som handler om etableringen av et privat pleiehjem på Finsland i Vest-Agder i tiden rett før frigjøringen. Romanens jeg-forteller skildrer i retrospektiv hvordan hans foreldre tar til seg flere psykisk utviklingshemmede, deriblant en søskenflokk fra Stavanger. Da vertsfamilien utsettes for en tragedie, utfordres synet på hvem som gir og hvem mottar omsorg samt begreper som galskap og normalitet. Artikkelen viser hvordan en skjønnlitterær fremstilling av forhold i nyere norsk åndssvakehistorie kan bidra til nye perspektiver på en historisk helse- og omsorgspraksis. Gjennom lesningen av Gaute Heivolls roman tematiseres praksisen med å plassere pasienter i privat pleie samt loven fra 1934, som ga adgang til å sterilisere psykisk utviklingshemmede.
\end{abstract}

Det finnes flere kjente skjønnlitterære skildringer av psykisk utviklingshemmede i norsk litteratur. Tusten i Tarjei Vesaas Fuglane

fra 1957 og Gabriel Scotts De vergeløse fra 1938 kanskje er de mest kjente. Scott skildrer hvordan barnehjemsbarn ble satt i privat pleie på landet, der de ble utnyttet og misbrukt. Romanen initierte en større debatt om forholdene for barnehjemsbarn i Norge. Gaute Heivolls roman fra $2013-$ Over det kinesiske hav (1) - berører noe av den samme tematikken.

Begge romanene omhandler sårbare barn og ungdommer som settes i privat pleie og er prisgitt tilfeldighetene når det gjelder hvordan de blir ivaretatt. I Scotts roman skildres overtramp og brutal behandling. Hos Heivoll behandles barna bra og lider ingen åpenbar nød, slik tilfellet er hos Scott. Men også karakterene i Heivolls roman er vergeløse $\mathrm{i}$ den forstand at de er satt under formynderi hos pleieforeldrene. De er dertil både barn og psykisk utviklingshemmet og slik sett enda mer sårbare enn Scotts barnehjemsbarn. I begge romanene tematiseres ordningen med at hjelpeog pleietrengende ble satt i privat pleie der rutinene for kontroll og kvalitetssikring var preget av tilfeldigheter.

Handlingen i Over det kinesiske hav (1) er lagt til det lille stedet Finsland i VestAgder og tar til i fredsåret 1945. Fortelleren er sønn av et kristent ektepar, som med yrkeserfaring fra Dikemark mentalsykehus bestemmer seg for å bygge et hjem som skal tjene som bolig for dem og deres to barn samt som omsorgsbolig for åndssvake. Etter hvert bosetter det seg tre psykisk utviklingshemmede ungkarer i ulik alder på loftet samt en søskenflokk på fem. Søsknene har vært utsatt for omsorgssvikt og har varierende grad av psykisk utviklingshemning. Båndene mellom søsknene er sterke, og eldstejenta Lilly fungerer som en mor for flokken. Da minstejenta til vergefamilien dør i en tragisk ulykke, bryter kjerne- familien sammen, og den gjenlevende broren oppsøker søskenflokken på loftet som erstatning for sin egen tapte familie.

Jeg ønsker i denne artikkelen å vise hvordan Gaute Heivoll i Over det kinesiske $h a v$ tematiserer forhold i nyere norsk åndssvakehistorie, nemlig praksisen med å plassere pasienter i privat pleie, og loven fra 1934, som ga adgang til å sterilisere psykisk utviklingshemmede. Ved hjelp av en historie basert på virkelige hendelser setter han søkelys på et lite påaktet tema.

Min lesning er støttet av sekundærlitteratur knyttet til historien om privat pleie av åndssvake i Norge samt litteratur som omhandler den lovbestemte norske steriliseringspraksisen fra 1934.

\section{Psykisk utviklingshemmede i privat pleie}

Ordningen med private pleiehjem var en reminisens av den gamle legdordningen, som gikk ut på å ha fattige og andre arbeidsuføre personer $\mathrm{i}$ arbeid for kost og losji på landet. Legdordningen ble formelt opphevet ved forrige århundreskifte, men mangelen på institusjonsplasser gjorde at den i realiteten levde videre. 28. juli 1949 vedtok Stortinget loven om hjem som mottar åndssvake til pleie, vern og opplæring. Den trådte i kraft 1. juli 1950 og innebar at asyl eller hjem som mottok flere enn to åndssvake i samtidig pleie, skulle få kompensasjon for de utgifter de hadde som følge av dette (2). Tanken var at dette skulle tjene som et økonomisk incitament for å opprette sårt tiltrengte plasser for psykisk utviklingshemmede. Mangelen på institusjonsplasser var prekær, og flere psykisk utviklingshemmede befant seg av mangel på noe bedre oppholdssted i sinnssykehus (3).

Over det kinesiske hav skildrer avslutningsvis hvordan den private omsorgsboligen jevnes med jorden i en kontrollert brann. Slik setter romanen et markant sluttpunkt for denne type omsorgspolitikk.

\author{
Linda H. Nesby \\ linda.nesby@uit.no \\ Institutt for kultur og litteratur \\ Fakultet for humaniora, samfunnsvitenskap \\ og lærerutdanning \\ Universitetet i Troms $\emptyset$ - Norges arktiske \\ universitet
}




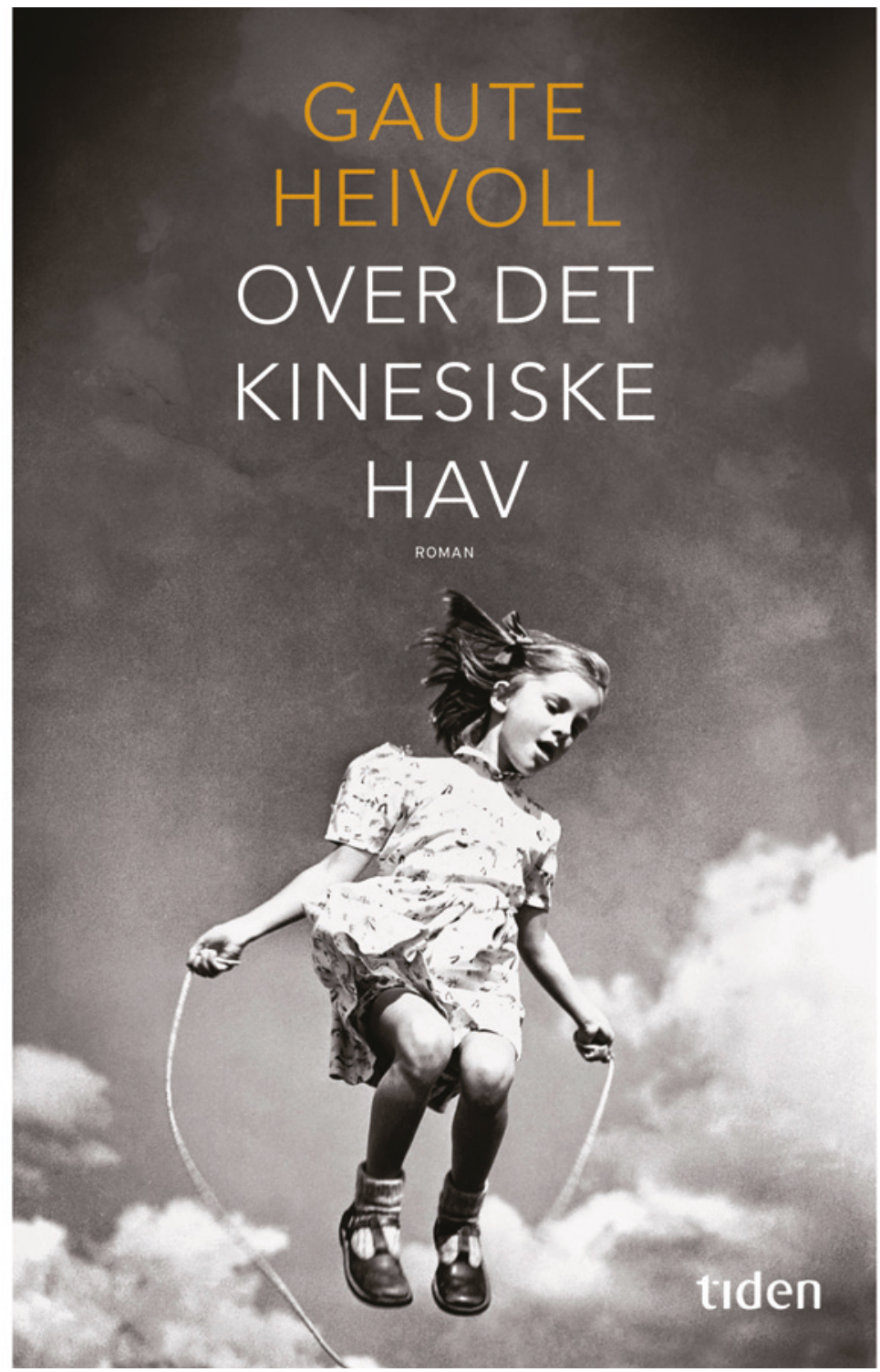

Omslaget på Gaute Heivolls siste bok

Romanen fremmer imidlertid ingen direkte kritikk av praksisen med privat pleie. Intensjonene skildres som gode og tuftet på et godt, kristent nestekjærlighetsideal:

Mamma og pappa hadde lagt planer for det nye livet i bygda på Sørvestlandet. De skulle reise et stort hus med mange rom og store vinduer. Sola skulle slippe inn fra morgen til kveld, loftstrappa skulle være bred og ha lave trinn slik at man ikke behøvde å løfte beina så høyt. Kjøkkenet skulle vært stort, og med plass nok til å lage mat til mange. Huset skulle bygges slik at de kunne ta imot pasienter - sinnssyke, pleietrengende krøplinger og åndssvake - og på den måten kunne de fortsette arbeidet ved Dikemark og forvalte Kristi kjcerlighets ånd. De skulle bygge sitt eget lille gale- hus midt i den bygda der pappa var født og oppvokst, den bygda som mamma foreløpig ikke hadde sett (1 s. 21).

Tanken er at huset på Finsland skal være et slags hjem for alle som bor der. Raskt etablerer beboerne på loftet en hverdag basert på rutiner og ritualer. Hierarkiet er likevel klart, noe som blant annet markeres ved at dørene bare kan låses fra utsiden og at det er husets biologiske barn som tar initiativ til lek med søskenflokken. Men da familien rammes av en katastrofe, blir spørsmålet om hvem som gir og hvem som får omsorg mer åpent.

Scenen der den femårige Tone dør, utgjør romanens dramatiske vending. Da en kjerre full av våt, tung grus under lek velter over den lille jenta, blir familieidyllen et mareritt. De som har gitt hjelp, greier ikke lenger å ta vare på seg selv. Foreldrene blir passive og tause, og selv den språkløse og psykisk utviklingshemmede Ingrid fremstår som mer kommunikativ enn omsorgspersonene i pleiehjemmet på Finsland. Tones dødsfall viser hvordan den tilsynelatende robuste kjernefamilien skakes, blant annet ved at barnas mor reiser fra familien i et forsøk på å bearbeide sin egen sorg. Søskenflokken på loftet utvides da til også å inkludere fortelleren:

Jeg hadde fått en blikktallerken, helt lik de andres. Etter hvert ble det nesten naturlig. Hver ettermiddag etter skolen gikk jeg opp trappa og banket lett på døra, og da var det dekket på til meg. Ingen spurte lenger om hvorfor jeg satt der. Pappa satt alene nede på kjøkkenet, mens jeg satt sammen med søsken-

flokken på loftet. Det var nesten naturlig (1 s. 101).

Mens kjernefamilien går i oppløsning, opprettholder de åndssvake på loftet sin veletablerte familiestruktur: De synger for maten og når de skal legge seg, storesøster Lilly samler sammen tallerkenene når de har spist, slår av lyset om kvelden når de skal sove og trøster den språkløse Ingrid når hun har det vanskelig. Heivolls roman viser styrken i søskenflokkens alternative familiekonstellasjon. Forholdet mellom pasienter og omsorgspersoner reverseres, og i tiden etter dødsfallet er det de åndssvake i omsorgsboligen som bidrar til hverdag og normalitet.

Da fortelleren oppsøker søskenflokken i voksen alder, finner han at samhørigheten dem imellom er den samme som før. I en kort samtale får han også bekreftet at de stadig husker hans søster som døde. Slik blir søskenflokken ikke bare representanter for en fleksibel og sterk familiestruktur, de blir også ivaretakere av familiært arvestoff som ellers ville gått tapt. Skildringen av den offentlige ordningen med privat pleie gis i Heivolls roman et nytt aspekt ved at de psykisk utviklingshemmede skildres som positive bidragsytere overfor vertsfamilien. I stedet for utelukkende å bli beskrevet som ressurskrevende pleiepasienter tegner romanen et bilde av de psykisk utviklingshemmede som givere av omsorg og nærhet i en prekær livssituasjon.

\section{Sterilisering}

Familiestrukturer og særlig morsrollen tematiseres i Heivolls roman. Både fortellerens foreldre og foreldrene til de psykisk utviklingshemmede søsknene fra Stavanger er i hele eller deler av romanen ikke i stand til å ta seg av barna sine. Det fremstår ikke minst sterkt når fortellerens mor reiser hjemmefra for å forsøke å få bukt med sin 
egen sorg etter tapet av yngstebarnet. Den som trer inn i morsrollen både for egne søsken og for fortelleren, er Lilly. Skildringen av Lilly som en morsfigur for flere av barna i romanen setter da også steriliseringen av henne $i$ et dramatisk lys.

Å sterilisere psykisk utviklingshemmede for å hindre dem i å bære frem barn med dårlig arvemateriale, var en del av den pseudovitenskapelige retningen kalt eugenikk. Eugenikk betyr direkte oversatt fra gresk «god slekt» og viser til forsøk på å påvirke arvemassens sammensetning enten ved å hindre barnefødsler hos dem som anses å være bærere av skadelige gener eller ved å øke barnetallet hos dem med positive gener. Eugenikkens mål var å forme befolkningens kvalitet gjennom ulike negative tiltak som blant annet sterilisering, ekteskapsregulering, segregering og integrering.

I 1869 ga den britiske vitenskapsmannen sir Francis Galton ut boken Hereditary genius, der grunnprinsippene innen eugenikken ble skissert, og i 1883 utformet han termen eugenikk. Galtons tanker var utbredt i 1900-tallets Europa. Sterilisering var opprinnelig ikke del av eugenikken, men vant gradvis innpass og ble etter den første verdenskrig et mye brukt virkemiddel. Praksisen rammet mennesker som falt utenfor samfunnsnormen, slik som psykisk syke, homoseksuelle, epileptikere og psykisk utviklingshemmede. I 1934 vedtok Stortinget en steriliseringslov. Loven ga individer adgang til sterilisering enten etter eget ønske eller etter anmodning fra verge, kurator eller andre med verge eller kurators samtykke. I lovens paragraf 4 heter det:

På sinnssyke og personer med særlig mangelfullt utviklede sjelsevner kan seksualinngrep tillates foretatt efter begjæring fra verge eller i $\S 6$ nevnte kurator, når det ikke er håp om helbredelse eller vesentlig bedring og det er grunn til å anta at vedkommende ikke vil bli i stand til ved eget arbeide å sørge for seg og sitt avkom, eller at en sykelig sjelstilstand eller en betydelig legemlig mangel vil bli overført på avkom, eller at han på grunn av en abnorm kjønnsdrift vil begå sedelighetsforbrytelser.

Begjæring om seksualinngrep kan i slike tilfeller også fremsettes av politimesteren i det distrikt hvor vedkommende bor; har vedkommende ikek [sic] fast bopel, kan den fremsettes av politimesteren i det distrikt hvor han opholder sig. Er vedkommende anbragt i fengsel eller tvangsarbeidshus eller i pleieeller opdragelsesanstalt, som står under offentlig tilsyn, kan begjæringen til like

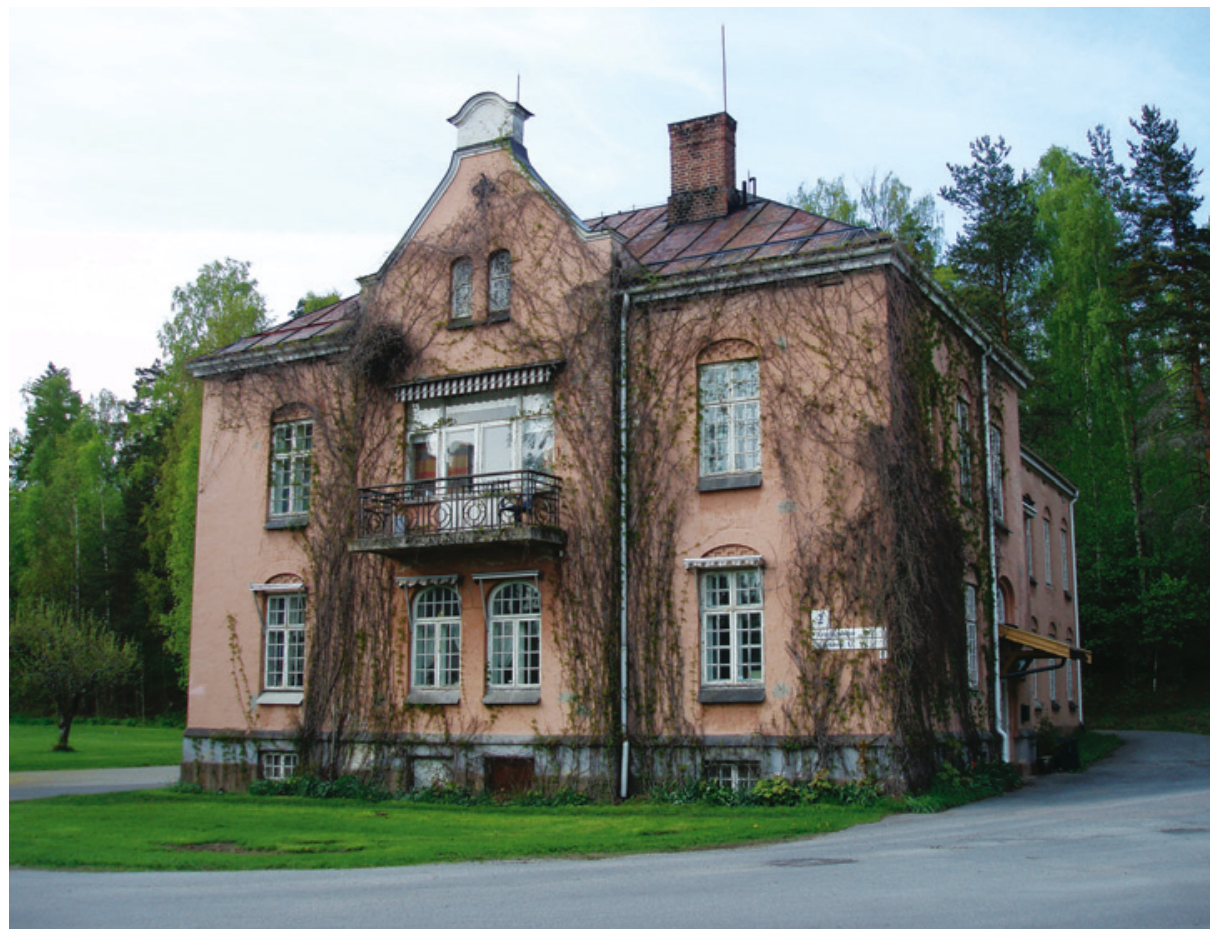

Dikemark sykehus. Foto: Peter John Acklam

fremsettes av anstaltens bestyrer. I begge de nevnte tilfelle kreves dessuten samtykke fra verge eller en kurator (4).

Liknende lovgivning ble i 1935 innført i hele Skandinavia samt i Tyskland, Sveits og de fleste amerikanske stater.

En av de fremste talsmenn for eugenikken i Norge var farmasøyten Jon Alfred Mjøen, som representerte en rasistisk form for rasehygiene. Mjøen ga i 1914 ut verket Racehygiene, der han hevdet at et moderne samfunn burde beskytte seg mot blant andre epileptikere, vanedrankere, kriminelle og åndssvake ved enten å segregere dem eller nekte dem avkom. Mjøen tok initielt innover seg vanskelighetene med å bestemme hva som var knyttet til arv og hva som skyldtes miljø. I innledningen til en ny utgave av verket fra 1938 er imidlertid tonen blitt mer kategorisk med hensyn til at miljøet kunne virke i positiv retning: «Dårlige arveanlegg kan ikke utryddes ved de mest ideelle omgivelser» (5). Mjøen var vitenskapelig sett omdiskutert og befant seg hele tiden på siden av akademia.

Større akademisk kredibilitet hadde den norske legen Johan Scharffenberg, som i 1930-årene uttalte at samfunnet hadde rett til å «(...) gripe regulerende ind i ordningen av menneskenes kjønnsliv» (6). Scharffenberg sympatiserte med Mjøens tanker om at sosialt reformarbeid knapt kunne kompensere for dårlige arveanlegg. Men i motsetning til Mjøen betonte Scharffenberg sterili- sering som det viktigste rasehygienske tiltaket. I 1932 uttalte han at målet måtte være å avskaffe «et urettferdig og planløst samfund, hvor de arbeidsdyktige ikke bare skal ernære sig selv, sine barn og sine gamle, men også må underholde en tilsynelatende stadig voksende hær av sinnssyke, åndssvake eller av annen grunn erhvervsudyktige individer» (7).

Argumentasjonen var altså ikke bare rasehygiensk, men også samfunnsøkonomisk basert. Til tross for at Scharffenbergs tanker virker tvilsomme i dag, var han i sin samtid en respektert skikkelse. Tankene om eugenikk ble ikke knyttet til nasjonalsosialismens kretsing om samme tema. Tvert imot var Johan Scharffenberg en av de første som advarte mot nazismen i Norge. Han falt da også i unåde hos den tyske okkupasjonsmakten og ble fratatt stillingen som overlege ved Oslo Hospital i 1941.

Det er lett å tenke at eugenikken hører til en fjern fortid, men også Karl Evang, helsedirektør fra 1938 og frem til 1972, anså det som viktig å redusere forekomsten av arvelig betinget åndssvakhet. En av de mest konkrete måtene å gjøre dette på var å ty til sterilisering av så vel menn som kvinner. Omtrent $12 \%$ av alle psykisk utviklingshemmede fruktbare kvinner i Norge ble sterilisert i perioden 1934-77, mens tallet for den mannlige delen av risikogruppen var $1 \%$ (8).

I Over det kinesiske hav blir hele søskenflokken sterilisert, to jenter og tre gutter: 


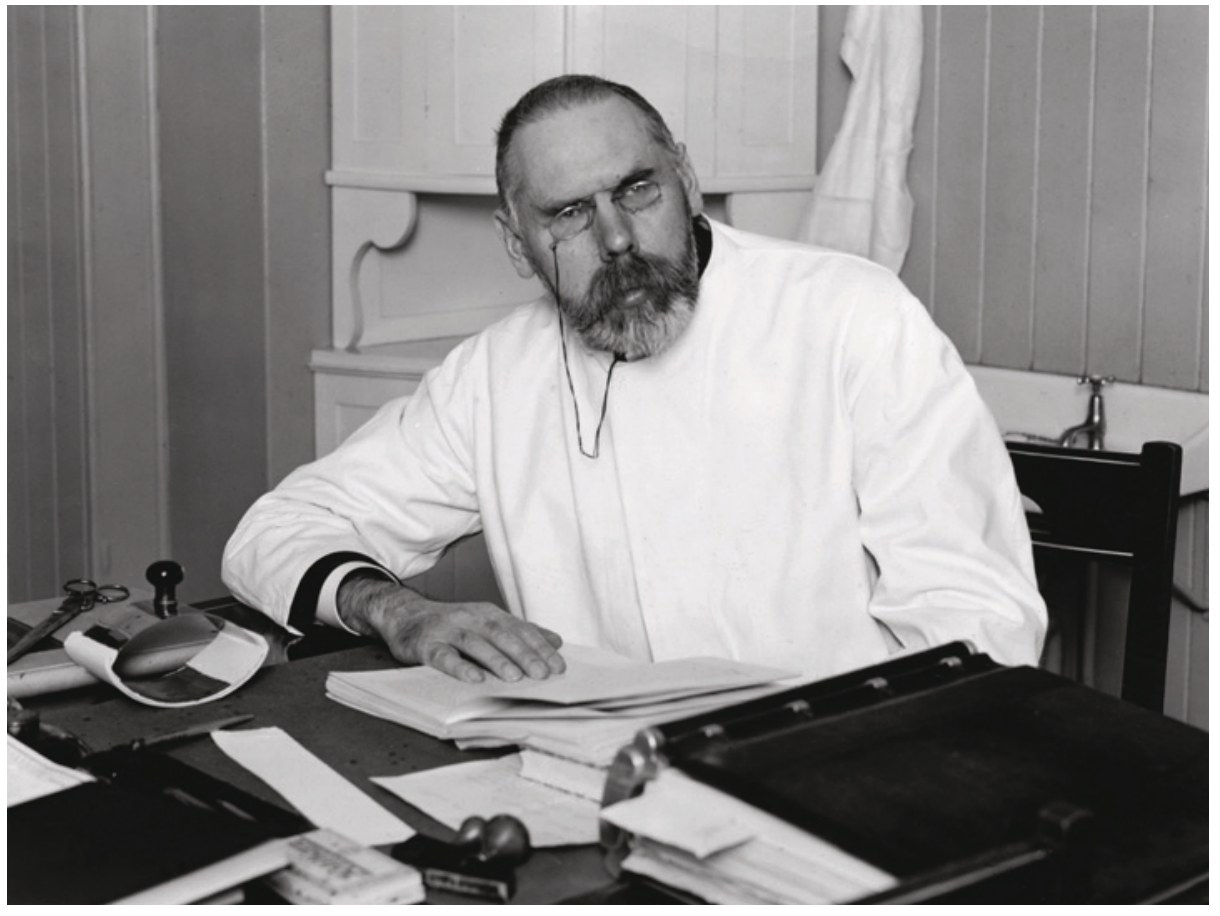

Johan Scharffenberg (1869-1965) var tilhenger av eugenikken. Samtidig advarte han meget tidlig mot farene ved nazizmen. Foto: NTB scanpix

«Vi forstod at noe viktig skulle skje, men straks ordet var nevnt, ble det verken utdypet eller snakket noe mer om. Lilly og Nils skulle ut på en viktig reise til Kristiansand, og de skulle være borte i flere dager» (1 s. 53). Det står ingenting om hvem som har tatt beslutningen - om det er ekteparet som driver pleiehjemmet eller om det kanskje er Lilly selv. Faren i vergefamilien følger dem til sykehuset og de kommer rolig med. Tilsynelatende foretas steriliseringen uten tvang. Flere av dem som ble sterilisert i årene etter krigen, skrev selv under på at de vedkjente seg inngrepet. I ettertid har man imidlertid vært kritisk til å kalle dette «frivillig sterilisering». Mange av dem som godtok inngrepet, har muligens ikke vært innforstått med hva de sa ja til eller vært klar over muligheten til å reservere seg (9).

Steriliseringen gis stor tekstlig plass i romanen. Til tross for at ingenting blir fortalt om selve inngrepet, vitner episoder både før og etter steriliseringen om alvoret knyttet til hendelsen. Da Lilly og Nils sendes til sykehuset i Kristiansand, blir de to yngste søsknene fortvilet. De gråter og roer seg ikke før etter mange timer. Også Tone, fortellerens lillesøster, smittes av uroen. Da søsknene legger seg for kvelden, forteller broren historien om den flygende appelsinkassen for å roe søsteren:

En gang var appelsinkassa full av appelsiner, og da fløy den over det kinesiske hav. Hvorfor den kunne fly, visste den bare selv. Så kom den først til Dikemark, og så tok mamma og pappa den med hit. Først sov jeg i den, deretter sov du i den. Men appelsinkassa har ikke glemt at den kan fly (1 s. 56).

Appelsinkassen representerer noe eksotisk som slår rot i nye omgivelser, ikke ulikt søskenflokkens flytting fra Stavanger til pleiehjemmet på Finsland. Ved å knytte kassen til foreldrenes jobb på Dikemark sykehus blir den et symbol for en omsorgsfunksjon som ikke er fiksert, men omskiftelig. Historien om appelsinkassen varsler den endringen i omsorgssituasjon som Tones død tvinger frem og som er så sentral i romanen. Den har gitt navn til romanen og at den skildres i forbindelse med steriliseringsscenen, markerer denne hendelsens betydning i romanuniverset.

Flere steder i romanen nevnes det hvordan Lilly fremstår som en mor for de yngre søsknene sine. Fortvilelsen deres da hun reiser fra dem for å bli sterilisert, vitner om at de også betrakter henne som sin aller nærmeste omsorgsperson. I forkant av steriliseringen betoner fortelleren at hun fremstår som en helt vanlig ung kvinne med typisk moderlige egenskaper:

Det slo meg igjen at Lilly egentlig var vakker. Hadde det ikke vært for søsknene, hadde det ikke vært for at hun bodde på loftet hos oss, da hadde hun nesten vært en vanlig kvinne med egne barn og mann, hest og noen kyr i fjøset, akkurat som oss. Hun sto der i en blomstrete kjole med et smalt tøybelte om livet, vinden tok tak i håret så det virvlet foran øynene hennes, og det var nesten ingenting som skilte henne fra de andre kvinnene i bygda.

Nesten ingenting (1 s. 53).

At Lilly fratas muligheten til å få egne barn, virker sterkt etter en slik beskrivelse. Da hun kommer tilbake etter sykehusoppholdet, er hun tilsynelatende upåvirket av det som har skjedd. Men bare tilsynelatende, for etter noen uker forsvinner hun. Hun blir funnet stående til knes i vann i en innsjø i det som fortoner seg som et hjelpeløst selvmordsforsøk. Hun berges i land og bringes tilbake til pleiehjemmet hvor livet fortsetter som for.

Lillys fortvilte rop om hjelp er likevel et signal om at steriliseringen var et overtramp. Fortellerens nøkterne observasjon av Lilly og søsknene da de møtes igjen etter steriliseringen, understreker hennes klare morsrolle: «[Lilly] var som en mor som hadde kommet hjem til barna sine» (1 s. 57). At hun er fra nå av biologisk er avskåret fra å få egne barn, viser stigmatiseringen knyttet til psykisk utviklingshemning i etterkrigstidens Norge.

Etter noen år blir også resten av søskenflokken sendt til sykehuset i Kristiansand. Det medisinske inngrepet blir heller ikke nå beskrevet, og skildringen av karakterenes reaksjoner fremstår fortellerteknisk effektivt og usentimentalt:

Den vinteren mens jeg var på Kvås, ble Ingrid og Erling sendt til Kristiansand og sterilisert på sykehuset $\mathrm{i}$ Tordenskjolds gate, akkurat slik Nils og Lilly hadde blitt det sju år tidligere. De dro de fire milene ut til kysten, og de fire milene hjem igjen. Jeg hørte ikke noe mer om det, og antok derfor at det foregikk uten protester. De kom tilbake etter noen dager, og så likedan ut som da de reiste. Noen år senere skjedde det samme med Sverre. Dermed var det fastlagt at fra Rebekka og Hertinius Olsens store barneflokk ville det aldri bli noen etterkommere (1 s. 153).

Heller ikke i beskrivelsen av dette steriliseringsinngrepet røpes det hvem som tok beslutningen. Som vist åpnet loven av 1934 for en rekke ulike varianter - kanskje var det frivillig sterilisering, kanskje var det faren i pleiefamilien eller vergerådet i Stavanger som formelt tok beslutningen om å la de fem søsknene steriliseres.

Romanens uklarhet omkring dette viktige punktet korresponderer med den oppsum- 
merende fortellermåten som preger skildringen av steriliseringen av søskenflokken. Den oppsummerende stilen signaliserer både en lojalitet til det offentlige helsevesenets beslutning og en nonchalanse og manglende forståelse av betydningen inngrepet hadde for dem som ble utsatt for det. Særlig gjelder dette Lilly. Mens de yngre søsknene i varierende grad beskrives som pleietrengende og utagerende, hevdes det gjentatte ganger at Lilly er «nesten som vanlig» (1 s. 53, 195). Skildringen av Lillys sterke reaksjon, samt den kortfattede opplysningen om at det er satt punktum for en familiegren, gir imidlertid et signal om at steriliseringspraksisen knyttet til de såkalt åndssvake kan forstås som dramatisk og med lite blikk for enkeltskjebner.

\section{Avslutning}

Over det kinesiske hav er basert på et medisinhistorisk faktum, nemlig praksisen med å plassere psykisk utviklingshemmede $i$ privat pleie og en lov som åpnet for adgang til å søke myndighetene om tillatelse til å få utført sterilisering. Til tross for sitt alvorlige tema er boken underholdende og lettlest, og forfatteren har selv kalt den sin mest humoristiske roman (10).

Utgangspunktet for romanen er den form for åndssvakeomsorg som var en historisk realitet frem til 1970-årene. Bakgrunnen for at søskenflokken fra Stavanger tas fra foreldrene og bringes til omsorgsboligen på Finsland, er historisk belagt. Det samme er deres flytting videre til en sentralinstitusjon og deretter til egen omsorgsbolig samt den brutale steriliseringspolitikken som de utsettes for.

Over det kinesiske hav skildrer hvilke ressurser psykisk utviklingshemmede er i besittelse av. Romanen viser også den bunnløse tragedien det er å miste et barn. Morsrollens sentrale stilling i romanen speiles dessuten i steriliseringen av søskenflokken fra Stavanger, særlig eldstejenta Lilly. Å miste et barn er en tragedie. Men å bli fratatt muligheten til å få barn, er også en stor sorg.

Romanen skildrer de psykisk utviklingshemmedes sårbarhet både ved overføringen fra egen familie til privat pleie og som en følge av den lovbestemte steriliseringspraksisen. Over det kinesiske hav problematiserer Johan Scharffenbergs eugenikkbaserte postulat fra 1914: «Vi må lære å skille mellom retten til at leve og til at gi liv» (11). Behandlingen pasientene i pleiehjemmet på Finsland får er god, men som psykisk utviklingshemmede er de likevel sårbare og prisgitt sine formyndere. Gaute Heivolls Over det kinesiske hav gir en sterk og nyansert skildring av et noe glemt kapittel innenfor nyere norsk åndssvakeomsorg.

\section{Linda H. Nesby (f. 1972)}

er litteraturviter og førsteamanuensis i nordisk språk og litteratur.

Forfatter har fylt ut ICMJE-skjemaet og oppgir ingen interessekonflikter.
Litteratur

1. Heivoll G. Over det kinesiske hav. Oslo: Tiden, 2013

2. Oppslagsbok for åndssvakeomsorgen. Oslo: Samordningsrådet for åndssvakesaken i Norge, 1949.

3. Fjermeros H. Åndssvak! Et bidrag til sentralinstitusjonens og åndssvakeomsorgens historie. Oslo: Universitetsforlaget, 2009: 180

4. Haave P. Sterilisering av tatere 1934-1977. En historisk undersøkelse av lov og praksis Oslo: Norges forskningsråd, 2000: 392

5. Mjøen J. Racehygiene. Kristiania: Jacob Dybwads forlag, 1914: 11

6. Det norske medicinske Selskab. Om arvesygdommer i lys av mendelismen. Referat av diskusjon. Kristiania: Det norske medicinske Selskab, 1912: 135

7. Det norske medicinske Selskab. Om arvesygdom mer i lys av mendelismen. Referat av diskusjon. Kristiania: Det norske medicinske Selskab 1912: 140.

8. Haave P. Sterilisering av tatere 1934-1977. En historisk undersøkelse av lov og praksis. Oslo: Norges forskningsråd, 2000: 154.

9. Schiøtz A. Folkets helse - landets styrke. 1850-2003. Oslo: Universitetsforlaget, 2003: 269

10. Biørnskau H. Heivoll tar oss med til galehuset. NRK. Kultur og underholdning. http://www.nrk.no/ kultur/litteratur/heivoll-tar-oss-med-tilgalehuset-1.11157460 (12.5.2014)

11. Scharffenberg J. Regjeringens forslag til steriliseringslov. Arbeiderbladet 26.4.1934.

Mottatt 4.3. 2014, første revisjon innsendt 15.5. 2014 godkjent 22.5. 2014. Redaktør: Anne Kveim Lie. 